\title{
Abolition and the Universal Carceral
}

$\mathrm{T}$ his edition of the Journal of Prisoners on Prisons is based, in part, on papers delivered at the 12th International Conference on Penal Abolition (ICOPA XII), hosted by the Howard League for Penal Reform in London on July 23-25, 2008. As part of ICOPA XII, the Journal of Prisoners on Prisons organized a Colloquium on the Universal Carceral, ${ }^{1}$ with the goal of creating "a space for focused discussion - within an abolitionist framework - about the changing and expanding dynamics of imprisonment, and about those aspects of the carceral experience that seem to remain constant across geography and time" (Howard League for Penal Reform, 2008, p. 3). The conference brought together academics, activists, ex-prisoners, lawyers and practitioners, and featured a number of works - several reproduced in this volume - written by current prisoners, but presented by delegates who were able to travel to London in their stead. The choice of London, England as the location for ICOPA XII struck many of us as apposite, given that the city has become the surveillance capital of the world, home to a vast and diffuse network of CCTV cameras that extinguished any expectations of privacy (see Surveillance Studies Network, 2006). Surely, there can be few better places to host a conference on penal abolition than a metropolis that is slowly and inexorably transforming itself into an open-air detention centre for vigilant citizen-prisoners.

Some of our deliberations engaged directly with penal abolitionism, considered as both a movement and as a stance (Mathiesen, this volume), while others represented efforts to map and define the "proliferation of new forms of carceral control" (Gaucher, 2007, p. 1). Both topics are reflected in this edition of the $J P P$, which is appropriate, as one of the key lessons of past ICOPAs is that the targets of the abolitionist movement are ever-shifting and diversifying, requiring a similar flexibility and openness from abolitionists. Indeed, as Mathiesen (1974) has argued, the strategy of penal abolitionists must be consciously and deliberately unfinished, pairing specific, targeted abolitions with a recognition of the consequent expansion of the boundaries of structures and systems of control, which in turn creates new targets for abolition.

The first ICOPA was held in Toronto, Canada, in 1983, and at the time, the focus was on prison abolition. While the prison remains central to the abolitionist movement, it was quickly recognized that focusing on the eradication of this institution without also addressing the punitive, exclusionary, and retributive policies and practices that drive incarceration, 
the long-term goals of abolitionism could not be realized. Accordingly, the second ICOPA expanded its focus from prison to penal abolition, a theme that continues to inform both targeted abolitionist efforts and efforts to build non-punitive, transformative, and community-based alternatives (Morris, 2000).

Unfortunately, the abolitionist goal remains elusive. Despite - or in some cases, through the co-optation of - the best efforts and intentions of reformers (Rothman, 1980; Cohen, 1985; Piché and Strimelle, 2008), the systematic deprivation of liberty through systems of control and confinement has intensified over time, driven by the expansion of the prison-industrial complex (Christie, 2000; Herivel and Wright, 2008), the proliferation of retributive policies and the rhetoric of penal populism, the large-scale adoption of carceral techniques (Foucault 1995 / 1977) in the realms of health and immigration, and the exceptionalizing politics of (in)security and neo-absolutism (Huckelbury, 2007). Bauman (2004) explains this growth of systems and spaces of exclusion as the consequence of an approach to modernity that allows whole categories of humanity to be essentialized and framed as (at best) redundant or (at worst) hazardous waste, subject to casting-out and enclosure (see also Young, 1999). It is this wholesale growth of the mentality of exclusion and its associated practices of surveillance, confinement and control that we attempted to address with the Universal Carceral Colloquium. In particular, we sought to highlight the proliferation and normalization of detention as a disposal or management tactic in spheres peripheral to the traditional criminal justice system, and to incorporate these spaces of confinement into the overarching abolitionist framework.

The issue begins with three articles that deal with health provision in prisons - a central topic discussed at ICOPA XII and one of the primary examples of the use of carceral techniques to deal with complex social problems. In "The Continuing Horror of Spiegelgrund", Peter Collins ${ }^{2}$ draws on two Canadian case studies to demonstrate the sheer incongruity between the needs of individuals dealing with mental illnesses and the characteristics of carceral spaces. While mental health issues require compassion and a recognition of vulnerability, prisons deliver isolation and coercion, with predictable and tragic consequences. Collins concludes by arguing that "[t]hese prison horrors exist and operate in your name, funded with your taxes. You have the right and frankly, the obligation to speak up". This call to action, fuelled by a dual sense of indignation and responsibility, is echoed throughout the issue, and sets the tone for our exploration of the Universal Carceral. In "Abrogation of the Therapeutic Model in Prison Health Care and the Implications for Public Safety", 
Susan Nagelsen and Charles Huckelbury ${ }^{3}$ continue the discussion of health care and imprisonment, this time with a focus on the United States. They describe a prison health care system that is structurally flawed and demonstrably incapable of meeting the needs of patients, and suggest that the perpetuation of this failure is made possible by the perceptual fallacy that prisons are disconnected from communities. Nagelsen and Huckelbury make the case for short-term abolitionist reforms, in the form of community-based alternatives to incarceration and the concomitant shifting of health care services to non-carceral spaces. Such a shift, they argue, will help to erode the sentiment of difference that allows the public to turn its back on prisoners, which will in turn facilitate long-term abolitionist goals. Eugene Alexander Dey, writing from California, discusses the "Correctional Asylums of the 21st Century" by providing a vignette of an attempted suicide by a prisoner. His argument is straightforward and powerful: the carceral environment, which threatens to break the spirit of the most resilient prisoners, is an inherently inappropriate place to put individuals dealing with complex mental heath issues.

Moving from the realm of health care to the realm of immigration - but continuing the discussion of incarceration as a tactic of exclusion that operates beyond a framework of "crime and punishment" - I, along with Sophie and Mohamed Harkat ${ }^{4}$ discuss the recent history of security certificate detention in Canada. In "Justice in Tiers", Sophie and Mohamed describe the practice of secret trials, where the precautionary logic of national security combines with the recognition of diminished rights for non-citizens to create a shifting system of indefinite detention, both within and outside the prison. Echoing Collins' call to action, we argue for the abolition of security certificates. In "Bush" (no, not George W.), Joe Lekarowicz talks about his disorienting experience as a prisoner in a United States immigration detention facility. He describes the atmosphere of systematic brutality and uncertainty that characterizes immigration detention, and provides a powerful account of the resilience provided by human relationships in dehumanizing places. I am happy to see these two articles published in the JPP as they shed light on forms and spaces of incarceration that are not generally discussed in these pages. The growth of immigration detention and the securitization of migration (Bigo, 2002), driven by resurgent nationalism and the fear of "Others", are key vectors in the expansion and universalization of the carceral.

The final article in the issue is "Political Prisoners in Australia?" by Craig W.J. Minogue. ${ }^{5}$ This article reminds us that abolition is a political project, the success of which depends in large part on the actions of politically-motivated prisoners. Minogue argues for a definition of political 
imprisonment that is based on the awareness and action of prisoners - and the state's response to these actions - as opposed to a determination of the motivations of the actions that led to their imprisonment. According to this framework, Australia has an active population of political prisoners, and Minogue calls on the transnational abolitionist movement to recognize and support this community.

Following the main articles, the issue continues with a special Response piece by Thomas Mathiesen on "The Abolitionist Stance". This article, based on his plenary address at ICOPA XII, directly engages with the questions "what is penal abolition?" and "how do we practice abolition?". Mathiesen argues that abolitionism is, first and foremost, a stance - an attitude of saying "no" that informs action. This stance has been at the heart of past successful abolitions, and, if maintained and fostered, will help us to realize the goals of penal abolitionism. I note that this stance, this attitude of saying "no" to systems of carceral control and of refuting arguments that they are in some way "necessary", informs each of the articles included in this volume of the JPP. This is encouraging. It shows, I think, that the abolitionist spirit is alive and well, and that our critical assessments of the disastrous consequences of incarceration are informed by a politics of hope, along with a rejection of the position that imprisonment need be viewed as a normal and inevitable part of our future.

This is a stance well worth adopting.

\section{ENDNOTES}

1 The Universal Carceral Colloquium was organized by Claire Delisle, Mike Larsen and Justin Piché. For more information, consult the colloquium website at http:// web.mac.com/mikelarsen1/The_Universal_Carceral/Welcome.html.

2 Presented at the panel "What is the Universal Carceral?" at ICOPA XII. Presented at the panel "Experiences of the Universal Carceral I" at ICOPA XII.

4 Based on presentations at the panels "What is the Universal Carceral?" and "Experiences of the Universal Carceral II" at ICOPA XII.

5 Presented at the panel "Experiences of the Universal Carceral II" at ICOPA XII.

\section{REFERENCES}

Bauman, Zygmunt (2004) Wasted Lives: Modernity and its Outcasts, Cambridge: Polity.

Bigo, Didier (2002) "Security and Immigration: Toward a Critique of the Governmentality of Unease", Alternatives, 27: 63-92. 
Christie, Nils (2000) Crime Control as Industry, New York: Routledge.

Cohen, Stanley (1985) Visions of Social Control, Oxford: Polity Press.

Ericson, Richard (2007) Crime in an Insecure World, Cambridge: Polity.

Foucault, Michel (1995 [1977]) Discipline \& Punish: The Birth of the Prison, New York: Vintage Books.

Gaucher, Bob (2007) “Editor's Introduction: Carceral Universals”, Journal of Prisoners on Prisons, 16(2): 1-7.

Herivel, Tara and Paul Wright (eds.) (2008) Prison Profiteers: Who Makes Money Off Mass Incarceration, United States: New Press.

Howard League for Penal Reform (2008) ICOPA XII Conference Report, http://www. icopa12london.org.uk/fileadmin/howard_league/user/pdf/Icopareport.pdf.

Huckelbury, Charles (2007) "Neo-Prussian Politics: Absolutism in the United States", Journal of Prisoners on Prisons, 16(2): 97-112.

Mathiesen, Thomas (1974) The Politics of Abolition: Essays in Political Action Theory, Oxford: Martin Robertson.

Morris, Ruth (2000) Stories of Transformative Justice, Toronto: Canadian Scholars Press.

Piché, Justin and Véronique Strimelle (2008) "Restorative Justice Program Evaluation Frameworks: A Site of Pitfalls and Opportunities", International Journal of Restorative Justice, 3(2): pp. 40-56.

Rothman, David J. (1980) Conscience and Convenience: The Asylum and Its Alternatives in Progressive America, New York: Aldyne de Gruyter.

Surveillance Studies Network (2006) A Report on the Surveillance Society: For the Information Commissioner by the Surveillance Studies Network, http://news.bbc. co.uk/2/shared/bsp/hi/pdfs/02_11_06_surveillance.pdf.

Young, Jock (1999) The Exclusive Society, London: Sage. 